\title{
Pelatihan "Great Mom Great Children" pada Ibu Muda Jalanan dalam Meningkatkan Ketrampilan Stimulasi Perkembangan Anak
}

\author{
Dessy Pranungsari ${ }^{1}$, Nissa Tarnoto ${ }^{1}$, Fatwa Tentama ${ }^{1}$ \\ Psikologi, Universitas Ahmad Dahlan, Indonesia ${ }^{(1)}$ \\ DOI: $\underline{10.31004 / o b s e s i . v 6 i 2.1161}$
}

\begin{abstract}
Abstrak
Anak jalanan perempuan yang memiliki anak di usia muda kurang memiliki pengetahuan dan ketrampilan dalam menstimulasi perkembangan anak. Tujuan dari penelitian ini adalah meningkatkan ketrampilan stimulasi perkembangan pada ibu-ibu muda jalanan dengan memberikan perlakuan berupa pelatihan "Great Mom Great Children". Subjek dalam penelitian ini adalah ibu merupakan anak jalanan yang tinggal di Yogyakarta, ibu muda yang berusia kurang dari 18 tahun saat memiliki anak, ibu yang memiliki anak atas kehamilan yang tidak dikehendaki, ibu memiliki anak berusia 0-5 tahun (anak usia dini), dan ibu mengasuh anaknya sendiri secara langsung. Desain eksperimen yang digunakan adalah untreated control group design with dependent pretest and posttest samples. Alat pengumpulan data menggunakan Kuisioner Pra Skrinning Perkembangan (KPSP). Hasil Uji Wilcoxon untuk menguji perbedaan tingkat ketrampilan stimulasi ibu-ibu muda jalanan antara sebelum (pretest) dan sesudah diberi perlakuan (posttest) menunjukkan adanya perbedaan yang signifikan antara skor pretest dan postest. Hasil Uji Mann Whitney $U$-test diperoleh hasil rata-rata tingkat ketrampilan stimulasi kelompok eksperimen lebih tinggi daripada kelompok kontrol. Hal ini menunjukkan bahwa metode pelatihan "Great Mom Great Children" efektif dalam meningkatkan ketrampilan stimulasi perkembangan anak pada ibuibu muda jalanan.
\end{abstract}

Kata Kunci: anak usia dini; ibu muda jalanan; keterampilan stimulasi

\begin{abstract}
The objective of this research was to examine the impact of "Great Mom Great Children" training to improve children development stimulation skill for young street mother. The subjects of the research young homeless mothers who are commonly referred to as a street mother. The subjects consisted of 8 young street mothers as an experimental group, and eight young street mothers as a control group with mean age 18 years. The type of research used is a quasi-experiment. Data collection using child developmental stimulation skills scale. The researchers perform Wilcoxon Test to examine the difference between stimulation skill level before and after the test. The result suggested that there was a significant difference before and after the treatment was given. It can be seen from $Z=-1,755$ and $p=0,079$ ) (2-tailed)/0, 0395 (1-tailed) with $p<0.05$. Also, the result of Mann Whitney U-test showed that the average level of stimulation skill in experiment group participant was higher than that of control group participant with the result of pretest-posttest $(\mathrm{p}=$ 0,074 (2-tailed)/ $\mathrm{p}=0.037$ (1-tailed) where $\mathrm{p}<0.05$ which mean significant. In conclusion, "Great Mom Great Children" training was an effective method to improve children's development stimulation skill for young street mothers
\end{abstract}

Keywords: early chillhood; stimulation skill; young street mother

Copyright (c) 2021 Dessy Pranungsari, et al.

$\triangle$ Corresponding author :

Email Address : dessyuad@gmail.com (Yogyakarta, Indonesia)

Received 22 Fabruary 2021, Accepted 15 May 2021, Published 10 August 2021 


\section{PENDAHULUAN}

Indonesia termasuk Negara Berkembang, yang juga memiliki permasalahan social yang berkaitan dengan anak-anak jalanan, yang secara Pendidikan dan ekonomi masih dibawah rata-rata pada umumuya. Remaja Perempuan yang hidup di jalanan adalah pihak yang paling berisiko mengalami kekerasan seksual dari lingkungannya (Pranungsari et al., 2014). Hal ini menybabkan banyak remaja perempuan menjadi Ibu diusia yang sangat muda. Berdasarkan data dari Yayasan DoMore Beberapa remaja perempuan menjadi Ibu Muda dibawah usia 18 tahun dan rata-rata Pendidikan mereka hanya tamat SD dan maksimal Pendidikan mereka SMP. Sebagian mereka ada yang menikah, ada juga yang menjadi orang tua tunggal. Hal ini juga didukung oleh pernyataan bahwa Ibu remaja lebih mungkin mengalami putus sekolah (Hoffmann, 2017), (Brown, 2015), tidak menikah dan menjadi orang tua tunggal (Brown, 2015), hidup dalam kemiskinan dan bergantung pada bantuan public (Brown, 2015), (Hoffmann et al., 2020).

Hal ini membuat mereka tidak siap menjadi Ibu, baik secara ekonomi, mental dan Emosi, dan hal ini pasti akan berdampak pada perkembangan anak kedepan. Beberapa penelitian telah menunjukan bahwa beberapa aspek lingkungan rumah seperti Pendidikan orang tua, status ekonomi, keterlibatan orang tua mempengaruhi perkembangan anak. Orang tua dengan Pendidikan, dan status ekonomi rendah menyebabkan anak mengalami masalah perkembangan Bahasa, social dan emosional (Brown, 2015), (Reardon \& Portilla, 2016).

Orang tua memiliki peran penting dalam perkembangan anak usia dini (Rahayu \& Dewi, 2018; Erzad, 2018), terutama Ibu. Pengetahuan Ibu terkait perkembangan anak akan sangat mempengaruhi bagaimana orang tua berinteraksi dengan anak dan Hal ini akan memberi manfaat yang bagus untuk perkembangan anak seperti perkembangan kognitif dan social emosional anak (Vreeburg et al., 2018). Namun pada kenyataannya tidak semua ibu muda memahami seperti apa pengasuhan yang terbaik bagi anaknya, terutama tentang pemberian stimuli untuk tumbuh kembang anak yang dapat mempengaruhi perkembangannya kelak. Berbagai hasil penelitian menyimpulkan bahwa perkembangan masa kanak-kanak mempengaruhi perkembangan anak di kemudian hari sehingga dapat meningkatkan produktivitas kerja mereka pada saat dewasa (Santrock, 2011). Jadi, memberikan rangsangan maksimal untuk anak-anak sangatlah penting. Dalam bidang pendidikan, stimulus sejak dini sangat dibutuhkan untuk memicu stimulasi bagi semua aspek perkembangan. Pada masa kritis ini, anak membutuhkan stimulasi untuk perkembangan potensi dirinya secara maksimal. Menurut Koshyk et al. (2020) bahwa intervensi maupun stimulasi yang dilakukan pada usia dini dibawah lima tahun akan berdampak positif bagi perkembangan anak. Beberapa penelitian mengemukakan bahwa salah satu yang menjadi penyebab perkembangan anak yang terhambat karena kurangnya stimulasi dari lingkungan sekitar termasuk keluarga (Flôres et al., 2019). Kondisi ini lebih memprihatinkan lagi pada ibu muda jalanan, yang mengganggap bahwa ketrampilan stimulasi adalah proses yang wajar dan otomatis datang pada waktunya. Padahal, penting bagi mereka untuk mengetahuinya dalam pemahaman lebih lanjut. Perilaku orang tua terhadap pengetahuan, sikap, dan praktik tentang keterampilan simulasi merupakan faktor penting yang harus dimiliki oleh mereka. Itu karena mereka dapat mengasuh dan mendidik anak-anak mereka dengan cara yang terbaik.

Hasil observasi dan wawancara dengan ibu muda menunjukkan bahwa masalah utama yang mereka hadapi adalah kebingungan dalam menstimulasi anaknya. Beberapa dari mereka khawatir tentang perkembangan terlambat yang mungkin terjadi pada anak-anak mereka. Kondisi ini semakin parah ketika mereka melihat anak kecil lainnya sudah bisa berjalan dan melakukan hal lain.

Masalah menjadi lebih kompleks ketika kebingungan ini menimpa ibu-ibu muda jalanan yang melahirkan pada usia kurang dari 18 tahun dan belum siap memiliki anak akibat hamil dalam perkawinan. Hasil wawancara (Pranungsari, 2015) yang dilakukan oleh peneliti sebagai studi pendahuluan terhadap ibu muda adalah ibu muda jalanan tersebut tidak memperdulikan masalah kesesuaian tahapan perkembangan anak, hal tersebut disebabkan 
karena mereka tidak memiliki pengetahuan dan keterampilan dalam merangsang tumbuh kembang anak. Ibu-ibu muda jalanan tidak tahu pada usia berapa seorang anak dapat berbicara, berjalan, bermain dan bersosialisasi. Ini kemudian mengakibatkan perkembangan kemampuan motorik, sosial dan emosional yang terlambat. Hal tersebut dikarenakan tidak adanya bimbingan dari orang tua atau kurangnya akses informasi pengasuhan anak.

Berdasarkan alasan tersebut, peneliti meyakini pentingnya memberikan psikoedukasi kepada ibu jalanan muda tentang keterampilan stimulasi. Hal ini dikarenakan pelatihan dapat meningkatkan pemahaman mereka tentang membesarkan dan menstimulasi anaknya sehingga dapat memberikan dampak positif bagi perkembangan anaknya di masa depan. Hal ini juga didukung penelitian Davies et al. (2017) bahwa orang tua semakin menyadari peran mereka dalam perkembangan anak setelah orang tua terlibat dalam proses intervensi, sehingga orang tua bisa belajar, memahami, dan merefleksikan peran mereka terhadap perkembangan anak.

Psiko-pendidikan bisa berupa pelatihan atau non-pelatihan (Himpunan Psikologi Indonesia, 2010). Dalam penelitian ini peneliti memberikan pelatihan. Penelitian yang dilakukan oleh (Pranungsari et al., 2014) mengemukakan bahwa penggunaan pelatihan terbukti efektif menurunkan risiko seksual dan kekerasan pada remaja perempuan di komunitas anak jalanan. Menurut Utami (2004) pelatihan merupakan suatu cara belajar dimana individu dapat meningkatkan pemahaman dan penguasaan keterampilannya.

Pelatihan "Great Mom Great Children" juga menekankan pada stimulasi anak dengan menggunakan benda-benda yang ada di lingkungan subjek penelitian, seperti stimulasi dengan menggunakan mainan daur ulang agar subjek penelitian dapat memanfaatkan barang apa saja yang ada di lingkungan tersebut untuk merangsang anak usia dini. Jadi, dengan menggunakan mainan daur ulang, mereka tidak akan menghabiskan banyak uang untuk membeli mainan yang merangsang. Mainan yang terbuat dari barang bekas telah terbukti mampu meningkatkan tumbuh kembang anak (Tarnoto et al., 2019), meningkatkan kemampuan motorik halus anak (Hidayatuna et al., 2020). Namun demikian peran guru tidak tergantikan oleh media apapun (Tatminingsih, 2019).

Hipotesis dalam penelitian ini adalah metode pelatihan "great mom great children" efektif dalam meningkatkan keterampilan stimulasi anak pada remaja ibu jalanan. Ada perbedaan tingkat keterampilan stimulasi anak antara sebelum dan sesudah metode pelatihan "great mom great children" pada kelompok eksperimen. Ada perbedaan tingkat keterampilan stimulasi anak antara kelompok eksperimen dan kelompok kontrol.

\section{METODOLOGI}

Penelitian dilakukan pada bulan April 2018 dengan subjek penelitian ini adalah ibu muda daerah jalanan di Kota Yogyakarta. Subjek dalam penelitian ini berjumlah 16 subjek yang terdiri dari 8 subjek kelompok eksperimen dan delapan subjek kelompok kontrol. Subjek penelitian adalah seorang ibu jalanan muda didampingi oleh Yayasan do More. Dari data 16 subjek yang ada, dibagi dua, delapan subjek sebagai kelompok eksperimen, delapan subjek sebagai kelompok kontrol. Semua subjek bersedia mengisi informed consent. Ciri-ciri subjek penelitian adalah Ibu muda tunawisma yang tinggal di Yogyakarta, Ibu muda berusia di bawah 18 tahun, Ibu dari kehamilan yang tidak diinginkan, Ibu yang memiliki anak usia 0-5 tahun, Ibu yang merawat bayinya sendiri.

Alat dan bahan yang digunakan dalam penelitian ini adalah sebagai berikut: Informed consent yang berisi persetujuan untuk berpartisipasi dalam penelitian ini, Kuisioner Pra Skrining Perkembangan (KPSP), Modul Pelatihan "Great Mom Great Children" disusun oleh peneliti , LKS Pelatihan: LKS evaluasi, LKS observasi, dan LKS partisipasi, Skala Ketrampilan Stimulasi Anak, Ruang kelas atau tempat diadakannya pelatihan, Perlengkapan audio visual seperti laptop, speaker, LCD, microphone, Botol daur ulang, majalah, koran, kotak, kayu, dll, Pensil / pulpen, gunting, dan lem), Kamera. 
Alat ukur yang digunakan dalam penelitian ini adalah Skala Pengembangan Keterampilan Stimulasi Anak. Skala keterampilan stimulasi ini dirancang berdasarkan kode stimulasi, deteksi dan intervensi dini perkembangan anak di pelayanan kesehatan dini (Kementrian Kesehatan RI, 2016). Adapun skala yang digunakan dalam penelitian ini adalah skala stimulasi keterampilan perkembangan anak. Skala stimulasi ketrampilan yang disusun peneliti mengacu pada pedoman pelaksanaan stimulasi, deteksi dan intervensi dini tumbuh kembang anak di pelayanan kesehatan dasar perkotaan yang akan didasarkan pada karakteristik stimulasi yang baik (Kementrian Kesehatan RI, 2016).

Butir soal skala yang telah diisi secara lengkap oleh 40 subyek ibu muda (bukan ibu muda jalanan) di TK Ar Royan, kemudian dipilih berdasarkan kriteria koefisien korelasi jumlah butir terkoreksi (rxy). Skala Pengembangan Keterampilan Stimulasi Anak menggunakan titik terendah 0,25 sehingga item yang memiliki gap index lebih tinggi atau sama dengan 0,25 memenuhi syarat untuk dimasukkan dalam skala penelitian. Hasil analisis uji terhadap 32 item skala berdasarkan alpha (a), didapatkan koefisien reliabilitas alpha 0,933 dengan indeks gap item (rit) meningkat dari 0,319 menjadi 0,864. Item yang valid dan reliabel sebanyak 32 item yang digunakan untuk penelitian ini.

Tabel 2. Contoh aitem Skala Ketrampilan Stimulasi Anak terdiri dari

\begin{tabular}{|c|c|c|}
\hline No & Karateristik & Contoh Aitem \\
\hline 1. & $\begin{array}{l}\text { Stimulasi dilakukan berdasarkan nilai cinta dan kasih } \\
\text { sayang. }\end{array}$ & Saya mengajari anak dengan penuh kesabaran \\
\hline 2. & $\begin{array}{l}\text { Mencontoh anak tentang bagaimana berperilaku baik } \\
\text { karena mereka akan selalu meniru orang terdekatnya }\end{array}$ & $\begin{array}{l}\text { Saya mendekat bila menyampaikan sesuatu } \\
\text { pada anak. }\end{array}$ \\
\hline 3. & Beri stimulasi sesuai usianya & Saya tidak memiliki lagu untuk anak-anak \\
\hline 4. & $\begin{array}{l}\text { Berikan berbagai stimulus dengan mengajak anak } \\
\text { bermain dan bernyanyi sesuai keinginan. Hindari } \\
\text { pemaksaan dan hukuman. }\end{array}$ & $\begin{array}{l}\text { Saya tetap tenang pada saat anak menolak } \\
\text { untuk diajak bermain }\end{array}$ \\
\hline 5. & $\begin{array}{l}\text { Merangsang langkah demi langkah dan terus } \\
\text { menerus sesuai dengan usia mereka dan } \\
\text { keterampilan dasar empat anak }\end{array}$ & $\begin{array}{l}\text { Saya mengajarkan anak berhitung secara } \\
\text { bertahap sejak usia dini agar dapat } \\
\text { merangsang tahap perkembangan otak anak } \\
\text { berikutnya }\end{array}$ \\
\hline 6. & $\begin{array}{l}\text { Gunakan alat bantu atau permainan sederhana yang } \\
\text { disimpan dan mudah ditemukan di sekitarnya }\end{array}$ & Saya membuat mainan yang aman bagi anak \\
\hline 7. & $\begin{array}{l}\text { Berikan kesempatan yang sama kepada anak laki-laki } \\
\text { dan perempuan }\end{array}$ & $\begin{array}{l}\text { Saya akan menjaga anak perempuan lebih baik } \\
\text { daripada anak laki-laki }\end{array}$ \\
\hline 8. & $\begin{array}{l}\text { Berikan penghargaan yang diperlukan untuk } \\
\text { pencapaian mereka }\end{array}$ & $\begin{array}{l}\text { Bagi saya memberikan hadiah atas } \\
\text { keberhasilan anak merupakan tindakan } \\
\text { pemborosan }\end{array}$ \\
\hline
\end{tabular}

Desain eksperimen yang digunakan dalam penelitian ini adalah eksperimen semu bukan eksperimen murni. Dalam penelitian tidak mungkin dilakukan eksperimen murni dan pengacakan subjek karena subjek harus memenuhi kriteria tertentu (Myers \& Hansen, 2012). Eksperimen ini menggunakan kontrol yang kurang ketat terhadap variabel ekstra, dan sampel tidak diambil secara acak.Pengacakan tidak dapat dilakukan karena pembagian subjek dalam kelompok diatur oleh yayasan do More. Peneliti melakukan Desain Kelompok Kontrol Tanpa Perlakuan dengan Sampel Dependent Pretest dan Posttest yang menggunakan kelompok eksperimen dan kelompok kontrol. Mereka diberi pretest dan posttest (Shadish et al., 2002).

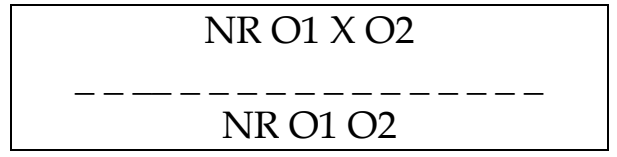

Gambar 1. Desain Eksperimen 
catatan:

$$
\begin{array}{ll}
\text { NR } & =\text { Tidak acak } \\
\text { O1 } & =\text { Pretest } \\
\text { X } & =\text { Pelatihan } \\
\text { O2 } & =\text { Posttest }
\end{array}
$$

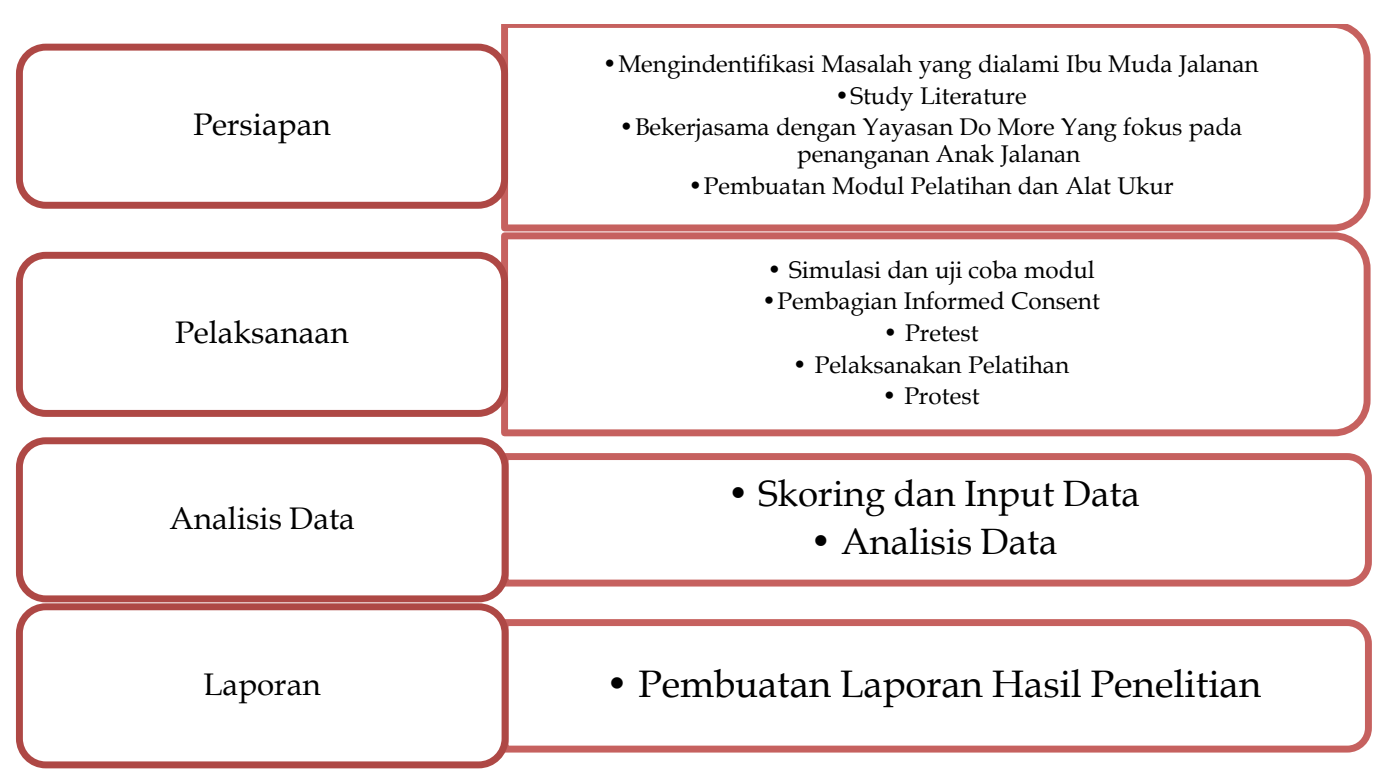

Gambar 2. Tahapan Penelitian

Penelitian terbagi menjadi empat tahap, dimulai dari tahap persiapan penelitian, pelaksanaan penelitian, Analisis Data dan Pelaporan hasil penelitian. Tahap persiapan penelitian, pertama Peneliti melakukan studi awal untuk memahami dan mengidentifikasi masalah yang dihadapi oleh remaja ibu jalanan. Para peneliti menemukan bahwa mereka harus membesarkan bayi pada usia yang begitu muda namun secara emosional mereka tidak stabil. Kedua, Peneliti melakukan studi pustaka dengan menganalisis jurnal dan karya ilmiah lainnya yang berkaitan dengan keterampilan stimulasi. Ketiga, Peneliti menjalin kerjasama dengan yayasan Do More untuk mendapatkan data dan informasi detail tentang subjek tersebut. Keempat, Setelah mempelajari beberapa literatur, peneliti menyusun modul pelatihan yang telah disesuaikan dengan karakteristik subjek penelitian. Modul menggunakan metode interaktif dengan melibatkan aktivitas audio visual atau kinestetik. Kelima, Peneliti merancang skala pengukuran menurut literatur setelah itu penilaian dan tes profesional dilakukan. Keenam, Peneliti mengelompokkan subjek dan menempatkan ibu jalanan muda berusia di bawah 18 tahun dalam satu kelompok (Subjek berusia antara 14 hingga 22 tahun), Ketujuh, Memilih tim pendukung, Tim pendukung dalam penelitian ini adalah asisten peneliti dari Do More Foundation. Tugas mereka membantu proses penelitian mulai dari persiapan hingga praktik. Mereka juga membantu memberi Skala Pengembangan Keterampilan Stimulasi Anak baik pretest maupun posttest. Tim dari Do More Foundation membantu peneliti menjalin komunikasi yang baik dengan ibu jalanan muda, mengumpulkan latar belakang pribadi subjek penelitian dan melakukan pelatihan agar peneliti dapat mengetahui lebih dalam permasalahan yang mereka hadapi.

Langkah Kedua adalah pelaksanaan penelitian. Pertama-tama Peneliti dan asisten peneliti membagikan informed consent kepada kelompok eksperimen dan kelompok kontrol. Persetujuan ini berkaitan dengan ketersediaan dan kesediaan untuk berpartisipasi sebagai subjek penelitian. Kelompok eksperimen juga diberi informasi tentang jadwal penelitian agar dapat berpartisipasi secara aktif. Kedua, Kelompok eksperimen dan kontrol semuanya diminta untuk menyelesaikan Skala Pengembangan Keterampilan Stimulasi Anak sebagai pretest sebelum diberikan pelatihan. Ketiga, Koordinasi dan simulasi modul dilakukan untuk 
memastikan kesiapan penelitian. Terakhir pelaksanaan "Great Mom Great Children" . Pelatihan ini dibagi menjadi lima sesi. Sesi satu: mengenali dan memahami perkembangan anak. Sesi dua: mengetahui pentingnya stimulasi bagi perkembangan anak, sesi 3: membuat mainan daur ulang untuk keperluan edukasi, sesi 4: ibu menjadi agen perubahan, sesi 5: praktik pemberian stimulasi pada anak.Setiap sesi dilakukan selama 2-3 jam menginap selama dua hari satu malam.

Para peneliti menggunakan statistik non-parametrik Mann-Whitney U-test untuk menganalisis data. Analisis ini digunakan untuk mengetahui perbedaan keterampilan stimulasi antara kelompok eksperimen dan kelompok kontrol setelah diberikan perlakuan.Keterampilan stimulasi diukur menggunakan skala perilaku Skema Keterampilan Stimulasi Perkembangan Anak, yang diterapkan pada sesi kelima selama pelatihan dan satu minggu antara waktu pelatihan dan posttest. Selain itu, Wilcoxon test juga untuk menguji dan menguji tingkat keterampilan stimulasi sebelumnya. dan setelah diberikan perlakuan untuk mengetahui signifikansi gap dari pretest ke posttest. Peneliti menggunakan analisis onparametrik karena data penelitian tidak berdistribusi normal. Analisis data dilakukan dengan menggunakan SPSS 17.0 for windows. Tahap terakhir dari penelitian adalah pembuatan Laporan Penelitian dan dilanjutkan publikasi artikel. Tahapan penelitian diilustrasikan pada gambar 2.

\section{HASIL DAN PEMBAHASAN}

Hasil uji Wilcoxon menunjukkan bahwa $Z=-1,755$ dan $p=0,079$ ) (2-tailed) / 0, 0395 (1-tailed) dengan $\mathrm{p}<0,05$. Artinya ada perbedaan yang signifikan mengenai keterampilan stimulasi pada ibu jalanan muda sebelum (pretest) dan sesudah (posttest) perlakuan diberikan. Rata-rata tingkat ketrampilan stimulasi setelah pelatihan lebih tinggi dibandingkan sebelum diberikan pelatihan. Selain itu, hasil uji homogenitas menunjukkan statistik Levene $=1,910$ dan sig =0,189 ( $>$ > 05). Dengan demikian, dapat dikatakan bahwa varians adalah homogen.

Tabel 2. Hasil Mann-Whitney U Test

\begin{tabular}{ccc}
\hline Data & Z & P. \\
\hline Pretest- & -1.789 & $\mathrm{p}=0,074(2$-tailed) \\
postest & & $\mathrm{p}=0,037$ (1-ekor) \\
\hline
\end{tabular}

Dari tabel 2 dapat disimpulkan bahwa secara umum perbedaan tingkat keterampilan stimulasi pada ibu jalanan muda antara kelompok eksperimen yang diberikan pelatihan dan kelompok kontrol yang tidak diberikan pelatihan adalah signifikan. Tingkat rata-rata keterampilan stimulasi pada kelompok eksperimen secara signifikan lebih tinggi dibandingkan dengan kelompok kontrol. Hal ini dapat dilihat lebih jauh dari Pretest-posttest $(\mathrm{p}=0,074$ (2-tailed) / $\mathrm{p}=0$ 0,037 (1-tailed) dimana $\mathrm{p}<0,05$ yang berarti signifikan.

Penelitian ini bertujuan untuk mengetahui efektivitas pelatihan "Great Mom Great Children" dalam meningkatkan keterampilan stimulasi pada remaja ibu jalanan. Hasil tes Wilcoxon menunjukkan bahwa ada perbedaan keterampilan stimulasi mereka sebelum dan sesudah pelatihan. Tingkat rata-rata keterampilan stimulasi setelah pelatihan secara signifikan lebih tinggi daripada sebelum pelatihan. Lebih lanjut, Mann Whitney U-test telah memberikan bukti yang lebih kuat bahwa keterampilan dalam kelompok eksperimen sekali lagi lebih tinggi daripada kelompok kontrol. Ini bisa menjadi bukti signifikan bahwa perbedaan itu disebabkan oleh pelatihan. Hal ini menunjukkan bahwa pelatihan "Great Mom Great Children" merupakan metode yang efektif untuk meningkatkan keterampilan stimulasi ibu jalanan.

Penelitian ini bukannya menentang anggapan bahwa ketrampilan stimulasi tidak bisa datang begitu saja, melainkan harus dilatih secara khusus kepada ibu muda sebagai sosok yang paling dekat dengan anak. Peran orang tua sangat penting dalam perkembangan anak 
(Erzad, 2018)sehingga perlu adanya pembinaan. Hal ini didikung oleh penelitian (Ansari \& Gershoff, 2016) yang menyatakan bahwa orang tua yang bergabung pada program "Head Start" terbukti dapat memperbaiki pola asuh mereka terhadap anak seperti meningkatnya pemberian stimulasi kognitif (miningkatnya literasi skill), menurunnya perilaku memukul dan mengendalikan. Program Head Start adalah Program untuk Anak Usia Dini dari kalangan kelas ekonomi bawah yang diadakan oleh Pemerintah Amerika, yang mengharuskan orang tua berpartisipasi dan terlibat dalam program, sehingga program harus dijalankan oleh orang tua. Hal ini bertujuan supaya keterampilan, pengetahuan dan pemahaman orang tua tentang Pendidikan dan perkembangan anak usia dini meningkat. Keterampilan dapat dikaitkan dengan perilaku. Sedangkan perilaku didasarkan pada sikap seseorang terhadap objek tertentu. Sikap memiliki tiga komponen utama. Mereka bersifat kognitif, afektif dan konatif (Baron \& Byrne, 2005).

Pemberian stimulasi kepada anak pada usia dini memiliki efek positif seperti meningkatnya kemampuan akademik jika anak akan bersekolah, meningkatnya perkembangan social emosional yang bisa mendukung kehidupan anak kelak (Ansari \& Gershoff, 2016; Jeong et al., 2019).

Kondisi lingkungan dan keluarga berdampak pada pola asuh orang tua dan perilaku anak (Sisyanti \& Adi, 2017). Seorang ibu muda dari komunitas jalanan memiliki resiko yang lebih tinggi untuk menghadapi masalah, oleh karena itu penting bagi mereka untuk diberikan pelatihan parenting untuk meminimalisir praktik yang salah dalam mengasuh anak. "Great Mom Great Children"pelatihan dirancang dengan mempertimbangkan setiap langkah penting untuk mendidik dan menciptakan perilaku yang baik. Sikap positif dalam pelatihan ini meliputi pemberian aspek kognitif dimana peserta diberikan pengetahuan tentang pentingnya stimulasi dan dampak yang mungkin timbul jika anak tidak distimulasi secara dini dan benar. Ini kemudian dapat menciptakan perkembangan yang terlambat. Dengan demikian akan terbangun pemahaman dan pemahaman tentang pengetahuan penting ini dalam memberikan stimulasi sejak dini kepada anak.

Dari sisi afektif, peserta akan menyadari dan mampu memicu perasaan baik dalam menstimulasi anaknya tanpa paksaan. Stimulasi dini penting untuk diberikan, karena akan berdampak pada perkembangan anak, anak yang diberikan stimulasi secara dini menunjukkan perkembangannya lebih baik daripada yang tidak mendpatkan sitmulasi. Hal itu bisa dihindari dengan memberikan stimulasi dini (Putra et al., 2018).

Setelah sikap yang baik terbentuk, peneliti mendorong orang tua untuk menstimulasi anaknya dengan mempraktekkan ilmu yang telah dipelajari dalam kehidupan nyata. Dengan demikian akan terjadi proses dimana peserta dapat memahami dan mengimplementasikan ilmu tersebut dalam kehidupan sehari-hari. Hal tersebut mendukung pendapat Utami (2004) yang mengatakan hal tersebut Pelatihan adalah cara belajar dimana individu dapat meningkatkan pemahaman dan penguasaan keterampilannya. Pada kasus ini,Pelatihan "Great Mom Great Children" terbukti efektif meningkatkan kemampuan stimulasi orang tua. Selanjutnya,Pelatihan ini dirancang sesuai dengan karakteristik peserta yang berasal dari komunitas jalanan dan memiliki pemahaman yang terbatas. Pembelajaran aktif juga dimasukkan dalam pelatihan ini dimana peserta dirangsang untuk aktif dalam setiap langkah seperti diskusi, refleksi dan role play.

Pelatihan ini melibatkan banyak gaya belajar antara lain audiovisual (film pendek tentang dampak yang terjadi ketika anak tidak distimulasi), kinestetik dimana peserta didorong untuk melakukan kegiatan di luar ruangan dan bermain peran. Tujuan dari role play adalah untuk menghindari kelas yang monoton yang dapat menimbulkan aktivitas yang membosankan. Hal ini dikarenakan peneliti menyadari keuntungan menggunakan pembelajaran aktif. Pembelajaran aktif bertujuan untuk mengoptimalkan proses pembelajaran, dan guru adalah orang yang menciptakan suasana belajar yang kondusif atau sebagai fasilitator dalam belajar, sementara peserta didik didorong untuk aktif, inovatif dan lingkungan dimanfaatkan sebagai sumber belajar yang kreatif, efektif, dan menarik didalam 
kelas (Uno et al., 2012). Pembelajaran aktif juga membuat siswa menjadi lebih percaya diri dan berpartisipasi aktif dalam proses pembelajaran (Rucket et al., 2014). Sebagai bagian dari kemampuan melihat karakteristik peserta, pelatihan ini juga dirancang dengan mempertimbangkan latar belakang peserta. Mereka terutama tidak mampu secara ekonomi, sehingga mereka didorong untuk menggunakan mainan yang murah dan terjangkau untuk merangsang anak-anak mereka. Mereka tidak perlu membeli mainan dengan harga mahal.

\section{SIMPULAN}

Pelatihan "Great Mom Great Children" adalah salah satu cara yang efektif untuk meningkatkan keterampilan stimulasi ibu jalanan. Penelitian ini hanya merupakan langkah awal untuk membantu ibu-ibu muda jalanan yang memiliki anak usia dini untuk memberikan pengasuhan maksimal kepada anaknya, sehingga harus ada tindakan tambahan untuk membimbing dan membantu remaja ibu jalanan dalam mengasuh anaknya. Tantangan dalam memberikan stimulasi akan semakin besar seiring dengan bertambahnya usia anak. Oleh karena itu, memberikan bantuan yang terbaik penting untuk membantu mereka membesarkan anak dengan baik.

\section{UCAPAN TERIMA KASIH}

Terimkasih kepada LPPM Universitas Ahmad Dahlan yang telah memberikan support kepada peneliti untuk melakukan penelitian ini.

\section{DAFTAR PUSTAKA}

Ansari, A., \& Gershoff, E. (2016). Parent Involvement in Head Start and Children's Development: Indirect Effects Through Parenting. Journal of Marriage and Family, 78(2), 562-579. https:// doi.org/10.1111/jomf.12266

Baron, R. A., \& Byrne, D. (2005). Psikologi Social (10th ed.). Erlangga.

Brown, A. L. (2015). The impact of early intervention on the school readiness of children born to teenage mothers. Journal of Early Childhood Research, 13(2), 181-195. https:// doi.org/10.1177/1476718X13479048

Davies, K. E., Marshall, J., Brown, L. J. E., \& Goldbart, J. (2017). Co-working: Parents' conception of roles in supporting their children's speech and language development. Child Language Teaching and Therapy, 33(2), 171-185. https://doi.org/10.1177/0265659016671169

Erzad, A. M. (2018). Peran Orang Tua Dalam Mendidik Anak Sejak Dini Di Lingkungan Keluarga. ThufuLA: Jurnal Inovasi Pendidikan Guru Raudhatul Athfal, 5(2), 414. https://doi.org/10.21043/thufula.v5i2.3483

Flôres, F. S., Rodrigues, L. P., Copetti, F., Lopes, F., \& Cordovil, R. (2019). Affordances for Motor Skill Development in Home, School, and Sport Environments: A Narrative Review. Perceptual and Motor Skills, 126(3), 366-388. https:// doi.org/10.1177/0031512519829271

Hidayatuna, Bahrun, \& Amalia, D. (2020). Penggunaan Media Bahan Bekas Untuk Mengembangkan Kemampuan Motorik Halus Anak Usia Dini Kelompok B Di Tk AlFitrah Aceh Besar. Jurnal Ilmiah Mahasiswa Pendidikan Guru Anak Usia Dini, 5(1), 4655. https:// doi.org/10.31004/obsesi.v5i1.667

Himpunan Psikologi Indonesia. (2010). Kode Etik Psikologi Indonesia. 131.

Hoffmann, H. (2017). Supporting teen families: an assessment of youth childbearing in Australia and early interventions to improve education outcomes of young parents. Life Course Centre Working Paper Series.

Hoffmann, H., Olson, R. E., Perales, F., \& Baxter, J. (2020). New mothers and social support: A mixed-method study of young mothers in Australia. Journal of Sociology. https://doi.org/10.1177/1440783320978706 
Jeong, J., Obradović, J., Rasheed, M., McCoy, D. C., Fink, G., \& Yousafzai, A. K. (2019). Maternal and paternal stimulation: Mediators of parenting intervention effects on preschoolers' development. Journal of Applied Developmental Psychology, 60(December 2017), 105-118. https://doi.org/10.1016/j.appdev.2018.12.001

Koshyk, J., Wilson, T., Stewart-Tufescu, A., D'Souza, M., Chase, R. M., \& Mignone, J. (2020). The ripple effect: Examining the impact on parents of an Abecedarian early child care intervention in an urban social housing development. Journal of Early Childhood Research. https://doi.org/10.1177/1476718X20966696

Myers, A., \& Hansen, C. (2012). Experimental Psychology (7th ed.). Belmont, CA.

Pranungsari, D. (2015). Hasil Wawancara Pemahaman Perkembangan Anak Usia Dini.

Pranungsari, D., Koentjoro, \& Kushartati, S. (2014). Psychoeducation of Healthy Dating to Reduce the Risk of Sexual Violence in Female Street Children. Journal of Educational, Health and Community Psychology, 3(3), 126-140. https:// doi.org/10.12928/jehcp.v3i3.3722

Putra, A. Y., Yudiemawati, A., \& Maemunah, N. (2018). Pengaruh Pemberian Stimulasi Oleh Orang Tua Terhadap Perkembangan Bahasa Anak Usia Toddler di PAUD Asparaga Malang. Journal Nursing News, 3(1), 563-571.

Rahayu, A., \& Dewi, T. (2018). Pengaruh Keterlibatan Orangtua Terhadap Perilaku. Golden Age Hamzanwadi University, 2(2), 66-74. https:// doi.org/10.29408/goldenage.v2i02.1024

Reardon, S. F., \& Portilla, X. A. (2016). Recent Trends in Income, Racial, and Ethnic School Readiness Gaps at Kindergarten Entry. AERA Open, 2(3), 233285841665734. https:// doi.org/10.1177/2332858416657343

RI, K. K. (2016). Pedoman pelaksanaan stimulasi, deteksi, dan intervensi tumbuh kembang anak. Kementrian Kesehatan RI.

Rucket, E., Plack, MM, \& Maring, J. (2014). Model Untuk Merancang Kursus Terapi Fisik Geriatrik Beralas Prinsip Pendidikan dan Strategi Pembelajaran Aktif. Jurnal Pendidikan Terapi Fisik, 28(1).

Santrock, J. W. (2011). Life-Span Development (Thirteenth). Mc Graw Hill.

Shadish, W. R., Cook, T. D., \& Campbell, D. T. (2002). Experimental and Quasi-experimental Designs for Generalized Causal Inference (second edi). Houghton Mifflin Company.

Sisyanti, \& Adi, I. R. (2017). Kajian Ecological System Mengenai Faktor. Jurnal Ilmu Kesehatan Sosial, 18(2), 113-123.

Tarnoto, N., Tentama, F., \& Pranungsari, D. (2019). Experimental study based on role play method to improve social skills for pre-school aged children of street. Humanitas, 13(3), 155-161. https:// doi.org/10.26555/humanitas.v13i1.3843

Tatminingsih, S. (2019). Alternatif Stimulasi Kemampuan Kognitif melalui Penerapan Model Pembelajaran Berbasis Permainan Komprehensif. Jurnal Obsesi : Jurnal Pendidikan Anak Usia Dini, 3(1), 183. https:// doi.org/10.31004/obsesi.v3i1.130

Uno, B., Hamzah, \& Nurdin, M. (2012). Belajar dengan Penedekatan Pailkem (Pembelajaran Aktif, Inovatif, Lingkungan kreatit, Efektif, Menarik). Bumi Aksara.

Vreeburg, L. E., Diekstra, R. F. W., Sklad, M. J., Lundy, C. D., \& Tough, S. C. (2018). Comparison of Canadian and Dutch Urban Parents and Grandparents in Terms of Knowledge of Children's Cognitive and Social-Emotional Development. SAGE Open, 8(2). https:// doi.org/10.1177/2158244018777027 